\title{
Political Institutions, Populism, and Democracy in Latin America
}

\author{
PATRICIO NAVIA AND IGNACIO WALKER
}

The end of the cold war coincided with the most widespread and successful wave of democratization that Latin America has experienced in its history. As the decade of the I980s drew to an end, democracy was on the way to becoming "the only game in town." Yet, two decades after the auspicious transitions to democracy, the results of the democratic experience have been decidedly mixed. On the one hand, elections have been broadly recognized as the only legitimate mechanism to select authorities; on the other hand, in many countries and along many dimensions, the quality of democracy is less than satisfactory. Public levels of support for democracy are disturbingly low in some countries. In others, concerns about corruption, low levels of participation, and institutional designs not conducive to adequate accountability point to glaring deficiencies in the region's democracies. Two decades ago, the countries in the region prioritized making transitions to democracy possible. Today, the major challenge consists of ensuring democratic consolidation. Democracy has to be a self-sustaining system capable of producing concrete and positive results for its citizens. When its exercise strengthens institutions, democracy will be a virtuous cycle that produces concrete results and satisfies international standards. In that sense, democracy must be self-sustainable (Przeworski 2005).

To take up the challenges faced by the countries of the region, we address two major themes in this chapter. First, we discuss the elements of democracy. We lay out formal criteria that must be present in order for a system to be democratic. We advocate a minimalist definition, and 
discuss conditions that have to exist in democracies. In this theoreticalpractical discussion, we explore one of the principal challenges in contemporary Latin America: the consolidation of democracy in a context conducive to populism. Democratic consolidation is undermined when populist leaders are legitimized in elections. In our discussion of this phenomenon, we stress the need to strengthen a "democracy of institutions," so as to minimize the possibility of a populist eruption. Because populism cannot be combated by limiting the electoral and participatory components of democracy, the best antidote to populism lies in strengthening democratic institutions.

Second, we broadly explore the quality of democracy in Latin America since I990. In doing so, we analyze the recent evolution of Latin American democracies in the context of the economic reforms adopted beginning in the r980s and into the r990s. We analyze how the combination of weak institutions, the persistent inequality of income, wealth and opportunities, and the negative reaction to some of the more deleterious effects of the economic reforms of the Washington Consensus ultimately favored the appearance of populism. In analyzing the recent experience of various Latin American countries, we show how strong institutions and sound social and economic policies contributed powerfully to consolidating democracy in some countries. However, we argue that in other countries the combination of less well-consolidated democratic institutions promoted populist leaderships resulting in political and social policies detrimental to either sustained development or to combating poverty and inequality.

\section{DEFINING DEMOCRACY}

Democracy is a system in which parties lose elections (Przeworski I99I). As such, democracy is constituted by a set of complex rules and procedures. Following Przeworski's definition, democracies have four essential characteristics.

First, democracies are systems. That is, there are rules of the game that have been decided on in advance and are fairly stable over time. These rules guarantee that there is a relatively leveled playing field for all. The rules of the game, regardless of how they were established initially, are accepted by most (preferably all) relevant political actors. The rules are of course subject to alteration, but the procedures through which they can be modified have also been established a priori.

A second essential characteristic, following Przeworski (I99I), who was inspired by Dahl's (I97I) classic definition of democracy as competi- 
tion among actors, is the existence of political parties. There is no stable democracy without political parties. Since contemporary democracies are essentially representative, political parties come to constitute principal vehicles for representation. In contrast to classic idealized definitions of direct participatory democracy, the complex systems of our modern societies favored the development of democracy based upon representation. Under democracy, electors entrust to their representatives the defense of their own interests and those of the country (Brennan and Hamlin I999; Manin I997).

Representative democracy cannot exist without political parties. Because of the information asymmetries that exist between those who govern and those who are governed, there must be incentives for representatives to build reputation. And there must be tools for voters to punish and reward authorities. Only when representatives run as members of political parties, voters can use information shortcuts and can reward or punish their past performance. Without parties, voters find it too costly to cast informed and meaningful votes in representative democracy.

In addition, political parties are an antidote to populist leadership. True, populism is almost the inevitable result of social and economic exclusion, especially in the context of weak institutions. Populist leaders promise to bring about inclusion. However, as with cholesterol, there is good and there is bad populism. After it successfully fosters social inclusion, a populist eruption should fade away. Yet, as populism is championed (almost by definition) by individual leaders rather than by political parties, it becomes the legitimizing force that helps keep the leader in power. Thus, if we understand populism as a likely outcome of social and economic exclusion, political parties advocating inclusion can win office and deliver on their promises without undermining democracy. But populist leaders promising inclusion will undermine institutions as they seek to fulfill their electoral promises.

Since the first half of the twentieth century, and as a result of demands for more social, economic, and political inclusion, populism has become a recurrent characteristic in the region (Cammack 2000; Di Tella I997; Weyland 2004). Populism has been identified with the weakness of democracy, both as a cause and as a consequence (Conniff I999; Dugas 2003; Hawkins 2003; Weyland 200I). But insofar as political parties are constituted adequately to represent the various strata of society effectively there will be a diminished possibility of Latin America's continuing to experience the proliferation of populist leaders (Navia 2003; Walker 2006a).

The third component of Przeworski's definition of democracy is the holding of elections. Modern democracy is essentially representative (Manin I997). In order for their representative components to function 
satisfactorily, democracies need elections. There exists a broad consensus on the necessity of holding regular, free, and informed elections that have reasonable eligibility requirements for candidates and mechanisms for guaranteeing universal suffrage as well as preventing fraud. However, there is less of a consensus on the mechanisms that accomplish these objectives. Nevertheless, although there is no universal formula for organizing legitimate elections, the quality of elections can be satisfactorily evaluated a posteriori. After an election, acceptance of the results by both winners and losers is the best evidence of the legitimacy of the electoral process.

The fourth component in this minimalist (but rigorous) definition of democracy is that elections are associated with uncertainty about the results. This constitutes both a requirement for democracy to function well and a test that it is functioning satisfactorily. When there is uncertainty as to the outcome, those involved know they must carry out a more arduous campaign - that they have to work harder-in order to triumph. The experiences of restricted democracies in which parties alternated in power and in which elections were not the determining factor in identifying who governed-and who would be left out-inevitably led the parties and the elite to ignore the electors. Such democracies evolved into systems with little transparency, and weak accountability.

The requirement for uncertainty in the electoral process cannot be limited only to its not being known in advance who is going to win an election. It is not enough to avoid the old custom in the Mexico governed by PRI, where elections (whose results were known before people voted) were "organized" by the party rather than held in a free and competitive manner. The component of uncertainty in the electoral process must also include an institutional design that makes such uncertainty serve the end of the voters' obtaining relevant information that will allow them to make informed decisions.

\section{DEMOCRACY AS A SYSTEM OF INSTITUTIONS}

Democracies are systems of institutions in which elections occupy a primordial space. But of course other components are also necessary for successful democratic consolidation. In democracy, the institutions constitute checks and balances that demarcate, limit, and restrain, but also facilitate and legitimize the exercise of power by democratically elected representatives (O’Donnell I998).

Traditionally, democratic systems have been classified according to their specific characteristics. Thus, for example, we distinguish between presidential democracies and parliamentary democracies. Other classifi- 
cations emphasize other criteria, like centralized, decentralized, or federal democracies. Others emphasize formal aspects of democracies, such as the attribution and distribution of powers between the executive and the legislative. Depending on their emphasis, there are different ways to classify and categorize democracies.

In Latin America, where presidential systems are the norm, various voices have questioned the suitability of maintaining presidential systems. Because they are said to be associated with greater stability and because they allow power to be less concentrated, parliamentary systems have often been pointed to as a suitable alternative (Linz and Valenzuela I994a, I994b). Other studies have focused on how particular sets of rules of the game affect the balance of power between the legislative and the executive, each set producing different results in the ability to reach agreements and enact laws (Alemán 2003, 2005; Alemán and Saiegh 2007; Cheibub, Przeworski, and Saiegh 2002, 2004). Some have pointed out that reforms contributing to decentralization can have positive, as well as negative effects for democracy (Eaton 2004; Jones et al. 2002; Montero and Samuels 2003).

All these contributions analyze specific aspects of democratic institutions in isolation from other components. Thus, although these studies are helpful in shedding light on one dimension or other, they do not result in a model that explains the overall interaction of the whole system. Tsebelis has suggested a novel alternative that seeks to unify various criteria for classifying democracies (2002). Instead of identifying the various institutions according to their type and distribution of their powers, Tsebelis suggests that we can understand democratic institutions in terms of the veto players present within the system. Some democracies have more veto players than others. In some democracies (centralized, presidential, unicameral, those where the executive has vast powers in relation to the congress), the number of veto players is smaller than in those with decentralized systems, bicameral systems, those having a constitutional court, an autonomous central bank, strong local governments, and a president with fewer powers in relation to the legislative branch. In advancing an understanding of institutions as veto players, Tsebelis makes it possible to compare the degree of influence of seemingly quite different institutions on the decision-making processes.

In this chapter, we use Tsebelis's proposition to better understand a phenomenon that has existed historically in Latin American democracies: populism. Although it made its appearance in the I930s and I940s as it sought to incorporate the growing masses of urban workers (Conniff I999; Di Tella 1965, 1997; Weyland 2001), populism has again become a recurrent phenomenon. Without entering into an extensive discussion about what constitutes populism and what political experiences may be 
considered populist (Barr 2003; Cammack 2000; Dornbush and Edwards I992; Dugas 2003; Hawkins 2003; Knight I998; Murillo 2000; Stein 1999; Szusterman 2000; Weyland 2001, 2003; Roberts 2007a, $2007 \mathrm{~b})$, for our purposes we define populism tentatively as the tendency of democratically elected leaders-usually presidents-to reduce the number of veto players in the political system.

Ours is consistent with other definitions of populism. Mayorga defines contemporary populism as "a pattern of personalistic and anti-institutionalist politics, rooted mainly in the appeal to and/or mobilization of marginalized masses" (2006, I34). Weyland sees it as "a political strategy through which a personalistic leader seeks or exercises government power based on direct, unmediated, uninstitutionalized support from large numbers of mostly unorganized followers" (200I, I4). Seeking to explain populism to a non-academic audience, Reid summarizes it as "two things: first, a brand of politics in which a strong, charismatic leader purports to be a saviour, blurring the distinction between leader, government, party and state, and ignoring the need for the restraint of executive power through checks and balances. Second, populism has often involved redistribution of income and/or wealth in an unsustainable fashion" (Reid 2007, I2). Most authors coincide in associating populism with a combination of high concentration of power in a single leader and weak institutional settings. In a context of weak institutions, the demand for redistribution seems to brew the emergence of populist leadership around a charismatic politician.

Accordingly, although populists may differ in the economic policies they adopt-some being considered "neoliberals" others more "traditional," and still others "neopopulists"-and on the emphasis they place on redistribution, they all share a propensity to reduce the number of veto players in the political system. Populist leaders are different from authoritarian leaders in that the former are legitimized electorally, time and time again, through relatively clean and competitive elections. Yet, they both prefer systems where the number of veto players is limited. This tendency often finds expression in conflicts between the democratically elected leaders and some institutions that "interfere"-for more or less legitimate reasons-with the new leaders' drive to carry out their programs and objectives (including their promises to bring about more inclusion).

\section{INSTITUTIONS AND LEADERSHIPS}

Because we understand populism as the tendency of democratically elected presidents to reduce the number of veto players in the political 
system, there is an obvious two-way relation between the initial strength of institutions and the emergence of successful populist leaders in Latin America. The stronger the institutions the less likely a populist attempt is going to succeed.

The conditions of social and economic exclusion under which populism usually emerges might be present in strong or weak institutional settings. In the former, demands for redistribution might feed populist temptations, but the strong democratic institutions will process those demands for redistribution and constrain the populist's attempt to concentrate power. In the latter, demands for redistribution will conduce to concentration of power in the hands of the populist president who rises to power promising to end inequality.

To be sure, charismatic leadership capable of mustering voters is essential for electoral success. Good candidates have the ability to communicate their proposals successfully and to mobilize potential voters by using their personal appeal. To be able to win elections, candidates must have popular appeal. But in a context in which democratic institutions are weak, charismatic leadership has a tendency to evolve into populism. Because presidential candidates receive a mandate from voters, they are tempted to concentrate power in their own hands to fulfill their electoral promises. Because weak democratic institutions do not provide for adequate checks and balances to executive power, charismatic leaders successfully consolidate power and become populist presidents. Whether they implement expansive fiscal policies or adopt neoliberal policies, chief executives, in the absence of solid democratic institutions, tend to evolve into populist presidents when institutional constrains on their power are absent, or are weak.

By contrast, when solid democratic institutions exist, the popularity of a winning presidential candidate can be transformed into a force that can induce support and cooperation from the institutions that exercise veto power over the adoption of new public policies. The more popular presidents are, the better able they are to advance their legislative agendas. When a solid democratic institutional context exists, popular chief executives are less likely to get away with populist instincts.

Table 7.I shows the interaction between the popularity of a president and the solidity of a nation's democratic institutions. Popular political leaders capable of demonstrating successful leadership qualities in the campaign and during their administration are more likely to become successful presidents if there is a context of solid democratic institutions. In contrast, they are more likely to face a populist temptation in a context of weak democratic institutions. On the other hand, unpopular presidents are often incapable of carrying out their agendas and fulfilling 
TABLE 7.I

Interaction Between Presidential Popularity and Strength of Democratic Institutions

\begin{tabular}{lll}
\hline & $\begin{array}{l}\text { Solid Democratic } \\
\text { Institutions }\end{array}$ & $\begin{array}{l}\text { Weak Democratic } \\
\text { Institutions }\end{array}$ \\
\hline Popular President & $\begin{array}{l}\text { Government can fulfill } \\
\text { campaign promises }\end{array}$ & $\begin{array}{l}\text { Government faces populist } \\
\text { temptation }\end{array}$ \\
Unpopular President & $\begin{array}{l}\text { Government fails to fulfill } \\
\text { campaign promises }\end{array}$ & $\begin{array}{l}\text { Lack of legitimacy and risk } \\
\text { of ungovernability }\end{array}$ \\
\hline
\end{tabular}

their campaign promises even when solid democratic institutions exist. The worst-case scenario is that in which solid democratic institutions do not exist and the president is unpopular. Under these conditions, there exists the risk of ungovernability.

In the following section, we explore the political evolution of Latin America from 1990 onward, in the context of the economic reforms adopted by most countries in the region. After discussing how these reforms were adopted, we analyze the emergence of recent populist regimes, and we compare these with what we define as non-populist regimes. Again, while the former are generally produced in weak democratic institutional contexts, the latter tend to appear in contexts of greater democratic and institutional strength. Finally, we argue that leadership matters: some leaders have contributed to consolidating democratic institutions while others have left a legacy of weakened democratic institutions.

\section{THE NEOLIBERAL ECONOMIC REFORMS OF THE \\ NINETIES AND THEIR OUTCOME}

The so-called "lost decade" (the I980s) in Latin America was characterized by massive foreign debt and serious macroeconomic problemsincluding very high inflation and budget deficits-arising from the economic policies implemented by various governments, such as those of Raúl Alfonsín (I983-I989) in Argentina, José Sarney (I985-I990) in Brazil, and Alan García (1985-I990) in Peru, all occurring amidst transitions to democracy. Subsequently, in the I990s the region experienced the introduction of numerous economic reforms commonly known as "neoliberal," and connected with what came to be known as the "Washington Consensus." 
In face of those realities, principally the fiscal and inflationary dilemmas, the Washington Consensus advanced ten specific proposals: control of fiscal deficits, clear standards on priorities for public spending, tax reform, interest rates and exchange rates (both were to be left to the market), liberalization of trade, opening to foreign investment, privatization of state enterprises, deregulation, and strengthening of property rights. ${ }^{1}$

A number of Latin American governments implemented a good share of these measures in the nineties, in some cases with significant popular support, in the face of serious macroeconomic disequilibria and the possibility of widespread social disruption. Carlos Andrés Pérez (I989-I993) in Venezuela, Carlos Salinas de Gortari (I988-I994) in Mexico, a series of governments-although with differing emphases-in Bolivia between the administration of Victor Paz Estensoro (I985-I989) and that of Gonzalo Sánchez de Lozada (2002-2003), Carlos Menem (1989-1999) in Argentina, Alberto Fujimori (I990-2000) in Peru, ${ }^{2}$ Fernando Collor de Mello (I990-I992) and Itamar Franco (I992-I994) in Brazil represented some of the exponents of these economic reforms carried out in the I990s, at the very time when economic and political stability was required to facilitate the transition from authoritarian rule. And although there exists a wide variety of differences among these governments, we might also include in this category the governments of Luis Alberto Lacalle (I990-1995) in Uruguay, Violeta Chamorro (I990-1996) in Nicaragua, and Sixto Durán (I992-I996) and Abdalá Bucaram (I996-I997) in Ecuador, among others.

Although many of the policies advocated by the Washington Consensus, especially those in the fiscal domain, were to matters of common sense rather than to an actual or supposed "neoliberal" ideology-such as those meant to ensure orderly fiscal accounts, low inflation, and a manageable foreign debt, the outcomes of these reforms generally fell far short of their promised objectives. Indeed, from the "caracazo" (the riots in Caracas) of 1989 , directed against the "neoliberal" reforms of Carlos Andrés Pérez in Venezuela, through the acts of repression that brought to an end the second administration of Gonzalo Sánchez de Lozada in Bolivia in October 2003 and which marked the beginning of the ascent to power of indigenous leader and coca farmer Evo Morales, a series of destabilizing situations occurred, culminating in some cases in the abrupt termination of administrations that, under a variety of circumstances, had earlier enjoyed significant popular support, as in the case of Carlos Menem in Argentina and Alberto Fujimori in Peru. After governing for a decade, both leaders ended up reviled and harshly criticized, especially when it came to corruption (in the case of Fujimori, he was later tried for human rights violations in Peru). 
POPULIST AND NON-POPULIST RESPONSES

The neoliberal economic reforms of the nineties precipitated two types of response in the region: the populist (more visible) and the non-populist, less visible than the former perhaps but more important from the point of view that concerns us, that is, democratic consolidation in Latin America and the central question of institution building.

The neoliberal reforms of the nineties triggered large-scale disruption, especially in countries that were experiencing a pronounced incapacity on the part of their governing elites and traditional political institutions to respond effectively to the social demands of emerging or long-ignored sectors: working and middle-class sectors whose living conditions deteriorated; indigenous peoples and social movements, urban and rural, emerging with unusual force; unemployed sectors, mainly made up of young city dwellers, capitalizing successfully on the discontent became a driving force in the region.

Opposition has erupted with unusual force where neoliberal economic reforms were the most profound and the institutions (or the political elites) the weakest, as in Venezuela, Bolivia, Argentina, Mexico, and Peru. These include the populist or neopopulist reactions personified by Hugo Chávez in Venezuela (I998 to present), Néstor Kirchner (2003-2007) in Argentina, Evo Morales (2006 to present) in Bolivia, and also-in spite of their having been defeated in recent presidential elections-by Andrés Manuel López Obrador in Mexico and Ollanta Humala in Peru, to mention only some of the most emblematic exponents of this populist or neopopulist reaction. The government of Rafael Correa in Ecuador would appear to be headed in a similar direction, after an election that pitted a populist of the right (Noboa) against a populist of the left (Correa), in a country that has had eight presidents in ten years. ${ }^{3}$ All these leaders share a discourse of antiglobalization and antineoliberalism and of opposition to the IMF and the Washington Consensus. Their countries undertook neoliberal economic reforms in the nineties (under Carlos Andrés Pérez in Venezuela, Carlos Menem in Argentina, Gonzalo Sánchez de Lozada in Bolivia, Carlos Salinas de Gortari in Mexico, and Alberto Fujimori in Peru). These countries have weak traditional elites and weak political institutions, especially in regard to their ability to channel emerging social demands.

This reaction contrasts clearly with the non-populist response found in other cases in the region, chiefly under the administrations of Fernando H. Cardoso (I994-2002) and Ignacio "Lula" da Silva (2002 to present) in Brazil; under the four Concertación governments in Chile headed by Patricio Aylwin (I990-I994), Eduardo Frei (I994-2000), Ricardo Lagos 
(2000-2006), and Michelle Bachelet (2006 to present); and in Mexico, under the administrations of Ernesto Zedillo (I994-2000) and Vicente Fox (2002-2006). To these we might add the governments of Tabaré Vásquez (2005 to present) in Uruguay, Leonel Fernández (2004 to present) in the Dominican Republic-especially when we consider that his presidency was preceded by the dismal populist experience of Hipólito Mejía (2000-2004), Martín Torrijos in Panama, Antonio Saca in El Salvador-more to the right, along with that country's last three administrations, Álvaro Uribe in Colombia, and certainly the governments of Oscar Arias and Alan García, in Costa Rica and Peru, respectively.

The three cases mentioned as the most emblematic of this non-populist reaction (Brazil, Chile, and Mexico) are particularly interesting. After having been preceded by governments that implemented neoliberal economic reforms-in the case of Chile most markedly under the Pinochet dictatorship, with the policies of the "Chicago Boys"-the governments of these countries have introduced significant corrections of a more heterodox and less dogmatic kind. Moreover, in each case a process of institution building has raised a wall of containment against the neopopulist temptation.

The results of this process are especially evident in Chile, where a coalition of parties, rather than any particular president, endeavors to implement a strategy of "growth with equity," with a consistent critique of both neoliberalism and neopopulism, and within a framework which has sought to engender broad consensus. In Brazil, the basic continuity between the economic policies of Cardoso and Lula has provided stability to the political and economic process of the last decade, after the implementation, under the government of Itamar Franco in 1994, of the "Real Plan." Particularly worthy of attention is that President Lula, with his long experience as a union leader, has resisted the temptation to populism, thus contributing to relieve the anxieties of the international financial community and the Brazilian business community-no small matter in a country that experienced four external financial shocks under the two administrations of President Cardoso (I995-2002), and also contributing to the stability of the overall political process, which has been bolstered further by the re-election of "Lula" in October 2006. Lastly, the case of Mexico is worthy of attention not simply in terms of democratic consolidation but also for the remarkable transition to democracy between Ernesto Zedillo and Vicente Fox. The victory of Felipe Calderón of the National Action Party (PAN) and the defeat of Andrés Manuel López Obrador in the 2006 presidential election is another demonstration of how, despite everything - including the very narrow electoral margin between the two candidates and the pressing conditions of 
poverty, social inequality, and marginality-Mexico has political and institutional resources to resist the neopopulist temptation.

It is precisely these three cases that Javier Santiso takes up to develop his theory about changes that have taken place in Latin America in the last thirty years in his book, Latin America's Political Economy of the Possible: Beyond Good Revolutionaries and Free Marketeers (2006). In Santiso's view, leaving behind the utopias that have traversed the history of the region since the conquest and the countless experiments that have taken place since the I950s, Latin America-the land of magic realismhas in its most recent history adopted a greater pragmatism. This new pragmatism is expressed not only in fiscal and monetary policies adopted in countries such as Chile, Brazil, and Mexico but also in the process of institution building, all of this leaving behind the extremes of the past. ${ }^{4}$ These three cases, along with Uruguay, the Dominican Republic, Panama, and El Salvador, and quite possibly Costa Rica and Peru, fit the category of non-populist reactions that are based on a "democracy of institutions" qualitatively distinct from the "personalistic democracy" of Chávez, Kirchner, and Morales. With nuances and variations depending on the case, these experiences evince a more pragmatic neoliberalism that (with the possible exceptions of Colombia and El Salvador) are more heterodox and less dogmatic compared to the neoliberal reforms of the region in the I990s.

To be sure, the case of Kirchner merits a special clarification. There are good reasons to include Kirchner as part of the populist responses to neoliberalism. First, kirchnerismo initially emerged and has consolidated within the tradition of Peronism. Peronism epitomizes Latin American populism. Second, there is still a strong element of concentration of power in the presidency under Kirchner. Third, there are weak democratic institutions in Argentina (Levitsky 2003). In that sense, we cannot speak of democracy of institutions properly when referring to the political system there. Yet, kirchnerismo should not be automatically equated to Chavez, and Morales, and so on and so forth. Argentina's democratic institutions have partially resisted the efforts by the executive to concentrate power. Thus, a democracy of institutions could easily reemerge in the future. The use of discretionary powers under the Kirchners' administrations has undoubtedly weakened democratic institutions, but much less so than in Venezuela or in Bolivia (where they were historically very weak).

Lastly, the cases of Paraguay, Nicaragua, Guatemala, and Honduras are "unfinished trajectories," somewhere between Democracies of Institutions and Personalistic Democracies, given their reactions, nonpopulist and populist, to the neoliberal reforms of the I990s. Our classification agrees with that found in the meticulous work of Mainwaring and Pérez-Liñán $(2006,5 \mathrm{I})$ on post-I978 democracies in Latin America, 
in which these four cases are referred to specifically as examples of "stagnation of semi-democratic regimes" in the region during the period in question. Figure 7.I gives an account of what we have said previously.

The non-populist reactions, commonly associated with what we have called democracy of institutions, contrast with neopopulist responses, commonly associated with personalistic democracies. While the former are represented especially by cases such as Brazil, Chile, and Mexico (among others) this latter type-of institutional weakness, associated with the emergence of populist leaders-is reflected in particular in the path followed by the Andean countries. ${ }^{5}$

René Mayorga (2006, I33) maintains that what is involved in these Andean countries is not only a crisis of representation but also a crisis of governability, the latter being the cause of the former. In Mayorga's view, the institutions of representative democracy have been the major victims here. In this context, "neopopulism" becomes a viable "political regime" characterized by personalistic and anti-institutional policies, a government based principally on appealing to the marginalized masses and possibly mobilizing them. Mayorga states, "In this regard, unlike historical populism, neopopulism is involved in the democratic game. It accepts the rules of democratic competition, but at the same time resorts to the higher quality and legitimacy of the leader, who presents himself as redeemer and embodiment of the people and the nation" (Mayorga 2006, I35).

Concerning what has been said up to here and what appears in Figure 7.I, we might stress the following points:

I. The region is not experiencing a general "leftist trend" of a neopopulist cut. Recent elections such as those of Álvaro Uribe in Colombia (2006) and Felipe Calderón in Mexico (2006)-and earlier, the election of Antonio Saca in El Salvador and the three presidents before him-run contrary to the claim. Second, we have not one, not two, but three lefts in Latin America, very different from one another: the Marxist left of Fidel Castro in Cuba, sectors within the Sandinista National Liberation Front (FSLN) in Nicaragua, and the Farabundo Martí National Liberation Front (FMLN) in El Salvador, the Chilean Communist Party, and numerous extra-parliamentary expressions in the region; the populist left of Chávez and Morales, which shows evidence of a growing convergence with the Marxist left; and the social democratic left, such of that of Lula in Brazil, Ricardo Lagos and Michelle Bachelet in Chile, Oscar Arias in Costa Rica, Leonel Fernández in the Dominican Republic, Martín Torrijos in Panama, or Alan García in Peru, in clear contradiction with the Marxist and populist left (Walker 2006b). 


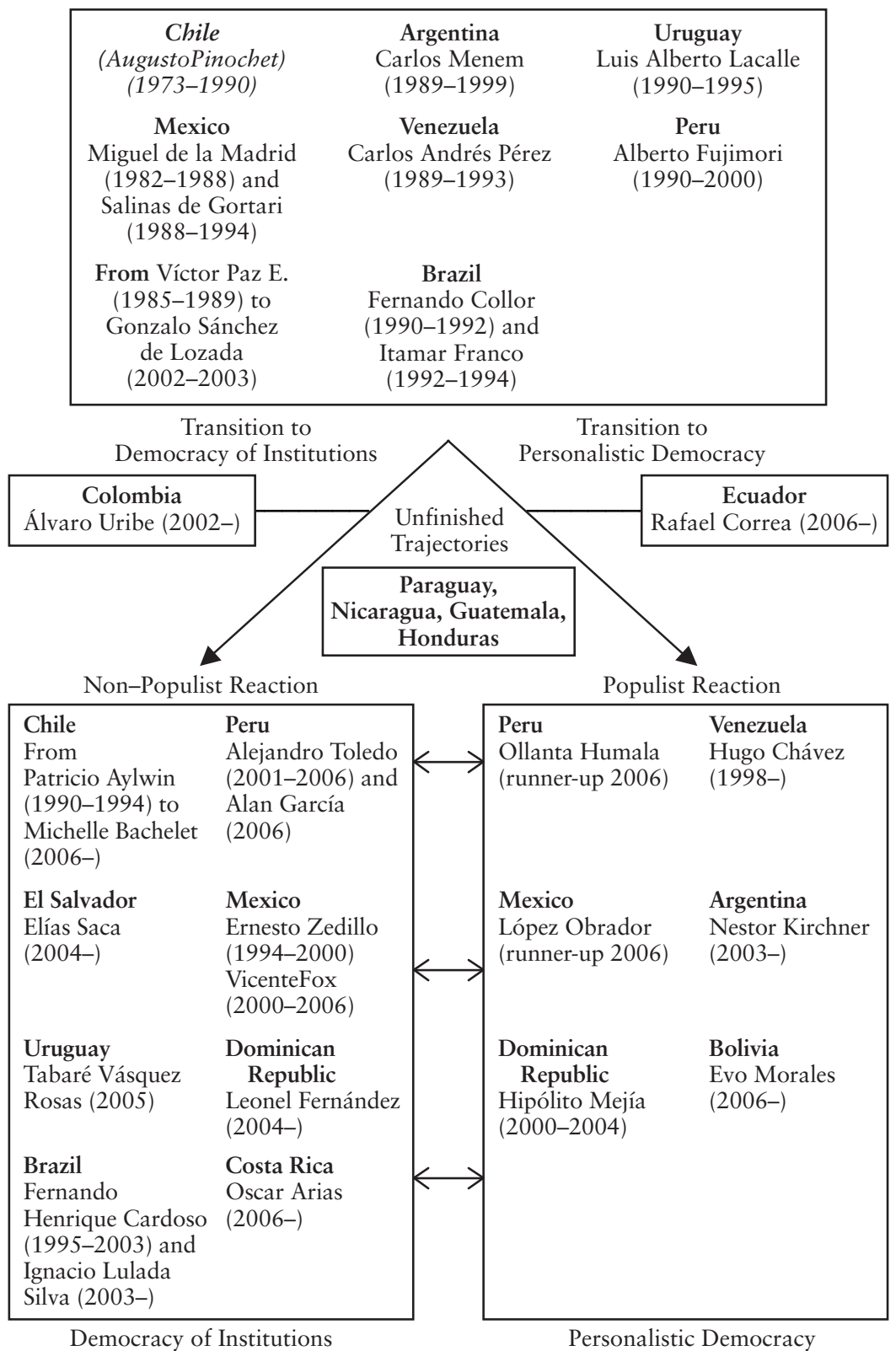

FIgURE 7.I Neoliberal Economic Reforms and Populist and Non-populist Reactions in Latin America 
2. It is not true that there exists a general populist reaction in opposition to the neoliberal economic reforms of the I990s. There does exist, along with a populist reaction, a non-populist path aiming at a democracy of institutions, different from the personalistic democracy of Chávez, Kirchner, or Morales. Along with its emphasis on institutions, the non-populist path also differs in that it has generally advocated a series of corrections to the neoliberal model, with heterodoxy taking priority over orthodoxy, so as to assure the sustainability of both the democratic institutions and economic and social reforms. In this context, non-populist reactions have had the know-how and ability to implement many of the economic reforms commonly associated with the Washington Consensus, without the ideological and dogmatic baggage of those reforms, at least in their original formulation.

3. Figure 7.I shows us that once there has been a passage from the neoliberal economic reforms of the r99os to the adoption of a non-populist path, it is very difficult to pass from there to a populist or neopopulist one. What is more, the electoral defeats in 2006 of López Obrador and Ollanta Humala, in Mexico and Peru respectively, show that democracies of institutions have significant popular support. And further, the passage from Hipólito Mejía to Leonel Fernández in the Dominican Republic demonstrates that there does indeed exist the reverse possibility of a trajectory from populism to non-populism.

4. Just as it has been said before, there also exist ambiguous, incomplete, and uncertain trajectories, such as those of Paraguay and some Central American countries such as Guatemala, Honduras, and Nicaragua.

5. Both forms of democracy (of institutions and personalistic, commonly associated with non-populist and populist paths respectively) are democratic forms of government and the governments that arise out of them are endowed with a formal democratic legitimacy. Nevertheless, in accord with what has been argued earlier, the democracy of institutions is the more functional in terms of the requirements for successful democratic consolidation.

\section{BY WAY OF CONCLUSION}

In this chapter we have adopted a procedural, minimalist definition of democracy, devoting our analysis to the tensions that arise between a democracy of institutions and one characterized by populist leadership 
and distinguishing between populist and non-populist paths followed after the neoliberal reforms of the nineties.

We have defined democracy, following Przeworski, as a system of institutions based on the irreplaceable action of political parties and the holding of free, periodic elections (representative democracy) with uncertainty as to the outcome. Following Tsebelis, we have defined populism tentatively as the tendency of leaders, usually presidents, to reduce the number of veto actors in the political system. We have amplified that by saying that while populist responses are generally produced in weak democratic institutional contexts, non-populist responses appear in contexts of greater democratic and institutional strength. Because we understand populism as personalistic leaderships that weaken institutions, there exists an obvious two-way interaction between the strength of the institutions and the appearance of personalistic leaderships in Latin America.

In our view, successful democratic consolidation is the product of the action of the institutions of representative democracy combined with the ability of the state to respond adequately to the demands of its citizens, especially in the socio-economic realm.

Twenty-five years ago, only Venezuela, Colombia, and Costa Rica had free, fair, and orderly regular elections in Latin America. The authoritarian wave that took hold in Latin America has yielded to a democratizing wave that is making its way as never before in the history of the region. In a twelve month period (from late 2005 to late 2006), elections were held in Honduras, Chile, Bolivia, Haiti, Costa Rica, Colombia, Peru, Mexico, Brazil, Ecuador, Nicaragua, and Venezuela. These twelve elections were significant in quantitative and qualitative terms. The election for the first time of a union leader (in Brazil), an indigenous leader (in Bolivia), and a woman (in Chile and Argentina); the holding of the cleanest presidential and parliamentary elections ever held in the history of Haiti-an example of a "failed state" in the region; the transition to democracy that has taken place in Mexico between Ernesto Zedillo and Vicente Fox (2000-2006) after seventy years of PRI hegemony; the widening of universal suffrage in terms hitherto unknown-all these are examples of the new democratic reality in the region.

At the same time, these gains take place in a social-economic context marked by the widespread reality of poverty, social inequality, exclusion, and marginality, which much of the time leads to the new reality of electoral democracy coexisting with deep skepticism with respect to the institutions of representative democracy, which are perceived as weak and remote. In spite of a period of unprecedented economic growth in 2004 , 2005, 2006, and 2007 throughout Latin America, fluctuating between 
an annual 4 and 5\%, more than 200 million people subsist below the poverty line, and Latin America remains the most unequal region in the world.

Consolidating a stable and vigorous democracy includes establishing solid institutions and a strong state that are capable of responding to accumulated social demands, especially those among the most neglected sectors of the population (Birdsall, de la Torre, and Menezes 2008). On an institutional level, there exists a general trend toward the establishment of strong presidentialism, with a significant degree of concentration of power in the executive, a development not accompanied by an increase in responsiveness to the demands of citizens. Along with this strengthened presidentialism, which is certainly related to the broad discrediting of parliaments and parties, there exists a trend toward a fragmented multipartism, with an ensuing difficulty of building stable governing coalitions. Many of the traditional bi-party systems of the region no longer exist (those in Uruguay, Colombia, Venezuela, Costa Rica, Nicaragua, among others), and fragmented multipartism has reached a truly alarming state in Brazil, Ecuador, Colombia, and Peru.

This fragmentation is possibly connected to a lack of agreement between different electoral majorities represented by the executive and the legislative, the problem of "double legitimacy." Under a presidential form of government, both the president of the republic and the legislature are directly elected by the people and thus both can claim to base their support on the popular will. Such a situation can easily lead to tensions between the two branches of the state as well as to a marked difficulty in forming stable majority coalitions for governing, all of which impacts democratic consolidation negatively. Along with the challenges at the institutional level, we find serious deficiencies in terms of the (in) effectiveness of states to respond to the growing, unsatisfied demands and expectations of their populations. This gap leads to a deepening of the problems of democratic (un)governability found on the institutional level. This is connected, for example, with the serious problems states face in designing, determining, and implementing public policies, and also generally goes along with the non-existence of technical personnel or a political-institutional design that would provide coherence and continuity to policies. Accordingly, it should not surprise us that in the last twenty years there have been fourteen governments in the region that did not finish out their terms of office. ${ }^{6}$ The subsistence of abrupt and unexpected government collapses confirms the difficulties faced by a region that has advanced significantly in achieving democratic consolidation. In that process, we have argued that the interaction of populist leadership with the strength of democratic institutions constitutes a decisive 
variable to explain populist and non-populist responses to the neoliberal reforms adopted since the I990s.

\section{Notes}

I. These measures are contained in Williamson (I990), which, together with his The Progress of Policy Reform in Latin America (Washington, DC: Institute for International Economics, I990), constitutes the foundation for the Washington Consensus.

2. Weyland (2003) refers to Menem and Fujimori as examples of "neoliberal populists," based on the synergies and affinities between economic liberalism and political populism, especially at the beginning of the nineties. At that time, the introduction and implementation of drastic neoliberal economic reforms paved the way to personalistic and plebiscitary leaders. This dynamic diminished in intensity in subsequent years.

3. Rafael Correa competed in the presidential election without having a single candidate for parliament, under the assumption (and the promise) that he would call a constituent assembly, a feature commonly associated with personalistic, populist, and plebiscitary democracy.

4. "The region's economies have propelled one of the most remarkable reform processes of their history, in tandem with a generalized movement toward democracy. Although incomplete and imperfect, this synchronized dual movement of economic reforms and a transition to democracy is very encouraging. To a large extent, this political and economic shift has been accompanied by an epistemic change. The reform policies enacted reflect a more pragmatic approach, a political economy of the possible" (Santiso 2006, 4).

5. This reality is precisely the subject of The Crisis of Democratic Representation in the Andes (Mainwaring, Bejarano, and Pizarro 2006), which recounts the crisis of democratic representation in Venezuela, Peru, Bolivia, Ecuador, and Colombia, one characteristic of which is the emergence of political outsiders with an anti-establishment discourse, whose rise is usually accompanied by a collapse of party systems. It is pointed out in this work that the delegitimization and decay of the party systems and the discrediting of the parliaments, in the wider context of the deterioration of the institutional channels of democratic representation, has "paved the way for plebiscitarian forms of representation in which populist presidents displace parties as the primary vehicles of expressing the popular will.... Thus, it might be argued that personalistic, plebiscitarian representation is simply displacing more institutionalized democratic representation" (Mainwaring et al. 2006, 30).

6. Fernando de la Rúa, Argentina (200r); Fernando Collor de Mello, Brazil (I992); Hernán Siles Suazo (I985), Gonzalo Sánchez de Losada (2003) and Carlos Mesa (2005), Boliva; Abdalá Bucarán (I997), Jamil Mahuad (I999), and Lucio Gutiérrez (2005), Ecuador; Jorge Serrano Elías, Guatemala (I993); JeanBertrand Aristide, Haiti (2004); Raúl Cubas Grau, Paraguay (1999); Alberto Fujimori, Peru (2000); Joaquín Balaguer, Dominican Republic (1994); and Carlos Andrés Pérez, Venezuela (1993). 


\section{References}

Alemán, Eduardo. 2003. Legislative Rules and the Amending Process: Theory and Evidence from Argentina, Chile and México. In The Annual Meeting of the American Political Science Association. Philadelphia Marriott Hotel, Philadelphia.

- - - 2005. The Origins of Presidential Conditional Agenda-Setting Power in Latin America. Latin American Research Review 40(2): 3-26.

Alemán, Eduardo, and Sebastián Saiegh. 2007. Legislative Preferences, Political Parties and Coalition Unity in Chile. Comparative Politics 39(3): 253-72.

Barr, Robert R. 2003. The Persistence of Neopopulism in Peru? From Fujimori to Toledo. Third World Quarterly 24(6): II6I-78.

Birdsall, Nancy, Augusto de la Torre, and Rachel Menezes. 2008. Fair Growth: Economic Policies for Latin America's Poor and Middle-Income Majority. Washington, DC: Center for Global Development and Inter-American Dialogue.

Brennan, Geoffrey, and Alan Hamlin. 1999. On Political Representation. British Journal of Political Science 29(I): I09-27.

Cammack, Paul. 2000. The Resurgence of Populism in Latin America. Bulletin of Latin American Research I9(2): I49-6I.

Cheibub, Jose A., Adam Przeworski, and Sebastián Saiegh. 2002. Government Coalitions under Presidentialism and Parliamentarism. Dados-Revista De Ciencias Sociais 45(2): I87-218.

- - - 2004. Government Coalitions and Legislative Success Under Presidentialism and Parliamentarism. British Journal of Political Science 34(4):565-87.

Conniff, Michael, ed. 1999. Populism in Latin America. Tuscaloosa, AL and London: University of Alabama Press.

Dahl, Robert A. I971. Polyarchy. Participation and Opposition. New Haven, CT: Yale University Press.

Di Tella, Torcuato. I965. Populism and Reform in Latin America. In Obstacles to Change in Latin America, ed. C. Véliz. London: Oxford University Press.

- - - I997. The Transformations of Populism in Latin America. Journal of International Cooperation Studies 5(I): 47-78.

Dornbush, Rudiger, and Sebastian Edwards. 1992. The Macroeconomics of Populism in Latin America. Chicago: University of Chicago Press.

Dugas, John C. 2003. The Emergence of Neopopulism in Colombia? The Case of Alvaro Uribe. Third World Quarterly 24(6): III7-36.

Eaton, Kent. 2004. Designing Subnational Institutions: Regional and Municipal Reforms in Postauthoritarian Chile. Comparative Political Studies 37(2): 2I $8-44$.

Hawkins, Kirk. 2003. Populism in Venezuela: The Rise of Chavismo. Third World Quarterly 24(6): II 37-60.

Jones, Mark P, Pablo Spiller, Sebastián Saiegh, and Mariano Tommasi. 2002. Amateur Legislators-Professional Politicians: The Consequences of PartyCentered Electoral Rules in a Federal System. American Journal of Political Science 46(3): 656-69. 
Knight, Allan. I998. Populism and Neo-Populism in Latin America, Especially Mexico. Journal of Latin American Studies 30: 223-49.

Levitsky, Steven. 2003. Transforming Labor-Based Parties in Latin America: Argentine Peronism in Comparative Perspective. New York: Cambridge University Press.

Linz, Juan J., and Arturo Valenzuela, eds. 1994a. The Failure of Presidential Democracy I: Comparative Perspectives. Baltimore: John Hopkins University Press.

- - - I994b. The Failure of Presidential Democracy II: The Case of Latin America. Baltimore: John Hopkins University Press.

Mainwaring, Scott, Ana María Bejarano, and Eduardo Pizarro, eds. 2006. The Crisis of Democratic Representation in the Andes. Stanford, CA: Stanford University Press.

Mainwaring, Scott, and Aníbal Pérez-Liñán. 2006. Latin American Democratization Since 1978: Democratic Transitions, Breakdowns, and Erosions. In The Third Wave of Democratization in Latin America: Advances and Setbacks, ed. Frances Hagopian and Scott Mainwaring, I4-59. Cambridge: Cambridge University Press.

Manin, Bernard. 1997. Principles of Representative Government. Cambridge: Cambridge University Press.

Mayorga, René. 2006. Outsiders and Neopopulism: The Road to Plebiscitary Democracy. In The Crisis of Democratic Representation in the Andes, ed. Scott Mainwaring, Ana María Bejarano and Eduardo Pizarro Leongómez. Stanford, CA: Stanford University Press.

Montero, Alfred, and David Samuels, eds. 2003. Decentralization and Democracy in Latin America. Notre Dame, IN: University of Notre Dame Press.

Murillo, María V. 2000. From Populism to Neoliberalism: Labor Unions and Market Reforms in Latin America. World Politics 52.

Navia, Patricio. 2003. Partidos políticos como antídoto contra el populismo en América Latina. Revista de Ciencia Política 23(I): 19-30.

O’Donnell, Guillermo. I998. Horizontal Accountability in New Democracies. Journal of Democracy 9(3): II 2-26.

Przeworski, Adam. I99I. Democracy and the Market. Cambridge: Cambridge University Press.

- - 2005. Democracy as an Equilibrium. Public Choice I23(3-4): 253-73.

Reid, Michael. 2007. Forgotten Continent (The Battle for Latin America's Soul). New Haven, CT: Yale University Press.

Roberts. Kenneth. 2007a. Latin America's Populist Revival. SAIS Review $27(\mathrm{I})$.

- - 2007b. Repoliticizing Latin America: The Revival of Populist and Leftist Alternatives. Democratic Governance and the "New Left," Woodrow Wilson Center Update on the Americas, Woodrow Wilson International Center for Scholars, Washington, DC, November.

Santiso, Javier. 2006. Latin America's Political Economy of the Possible: Beyond Good Revolutionaries and Free-Marketeers. Cambridge, MA: MIT Press. 
Stein, Steve. 1999. The Paths to Populism. In Populism in Latin America, ed. Michael Conniff. Tuscaloosa and London: University of Alabama Press.

Szusterman, Celia. 2000. Carlos Saúl Menem: Variations on the Theme of Populism. Bulletin of Latin American Research I9(2): 193-206.

Tsebelis, George. 2002. Veto Players: How Political Institutions Work. Princeton, NJ: Princeton University Press.

Walker, Ignacio. 2006a. Democracia en América Latina. Foreign Affairs en Español 6(2).

- - - 2006b. Qual é o caminho da globalização, da democracia e da esquerda na América Latina? Política Externa I5(2): 2I-32.

Weyland, Kurt. 200I. Clarifying a Contested Concept: Populism in the Study of Latin American Politics. Comparative Politics 34(I): I-22.

- - 2003. Latin American Neopopulism: Neopopulism and Neoliberalism in Latin America; How Much Affinity? Third World Quarterly 24(6): I095-II5.

- - - 2004. Neoliberalism and Democracy in Latin America: A Mixed Record. Latin American Politics and Society 46(I): I35-57.

Williamson, John. 1990. Latin American Adjustment: How Much Has Happened. Washington, DC: Institute for International Economics. 
